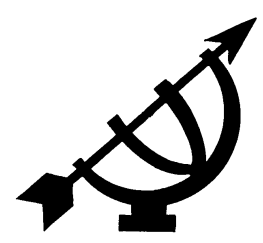

\title{
'n Psigo-opvoedkundige ondersoek na enkele vooronderstellings en konsepte onderliggend aan die Neurolinguistiese Programmeringsmodel
}

\author{
C.M. Vorster \\ Departement Kurrikulumstudie \\ Universiteit van die Vrystaat \\ BLOEMFONTEIN \\ E-pos: vorstercm.hum@mail.uovs.ac.za \\ J. du Plooy \\ Fakulteit Bestuurswetenskappe \\ Sentrale Universiteit vir Tegnologie, Vrystaat \\ BLOEMFONTEIN \\ E-pos: johann@sac.fs.gov.za
}

\begin{abstract}
A psycho-educational investigation into a few suppositions and concepts underlying the Neuro-linguistic Programming model
\end{abstract}

In the early 1970s a model was developed to identify the therapeutic methods that were used by outstanding psychologists. Eventually the so-called Neuro-linguistic Programming (NLP) model was introduced and this model is still used today in many fields such as in psychotherapy with children, in teaching, in the business world and so forth. The purpose of this article is to shed more light on the main presuppositions and concepts underlying the NLP model. This investigation will mainly be undertaken from a psycho-educational perspective. It will, however, also be attempted to concentrate on application possibilities (if any) of NLP concepts, taking a Christian point of departure. The most important NPL concepts will be discussed in relation to children on their way to adulthood, whether they are in therapy or in a classroom situation. In conclusion, while referring to the relevance of NLP in psycho-education, certain transcendental-critical perspectives will be provided concerning the most important concepts and presuppositions of NLP. 


\section{Opsomming}

\section{'n Pslgo-opvoedkundige ondersoek na enkele vooronderstellings en konsepte onderliggend aan die Neurolinguistiese Programmeringsmodel}

Vroeg in die sewentigerjare is 'n model ontwikkel om terapeutiese metodes wat deur uitnemende sielkundiges gebruik is te identifiseer. Uiteindelik is die sogenaamde Neurolinguistiese Programmeringmodel (NLP) daargestel en hierdie model word vandag op vele terreine aangewend - byvoorbeeld in psigoterapie met kinders, in die onderwys, in die sakewêreld, ensovoorts. Die doel van hierdie artikel is om meer lig te werp op die belangrikste vooronderstellings en konsepte wat NLP onderlê. Hierdie ondersoek word hoofsaaklik onderneem vanuit 'n psigo-opvoedkundige perspektief. Daar word egter ook gepoog om te konsentreer op toepassingsmoontlikhede (indien enige) van NLP-konsepte vanuit 'n Christelike vertrekpunt. Die belangrikste NLP-konsepte wat verband hou met die situasie van kinders op pad na volwassenheid word bespreek, of hulle nou terapie ontvang of in 'n klaskamersituasie is. Hoewel voortdurend verwys word na die tersaaklikheid van NLP in die psigo-opvoedkunde word sekere transendentaal-kritiese perspektiewe aangaande die belangrikste konsepte en vooronderstellings van NLP ten slotte gebied.

\section{Inleiding}

'n Terapeutiese program/werkwyse wat al hoe meer gewild word en tans ook in onderwyskringe inslag vind, word aangedui as Neurolinguistiese Programmering (NLP). Alhoewel NLP aanvanklik hoofsaaklik in terapeutiese motiveringsituasies toegepas is om die proses van kommunikasie te bevorder, raak die aanwendingsfeer van NLP tans al hoe meer uitgebreid (Blackerby, 1996:189; Dilts, 1998:3; Bester, Nainaar \& Roodt, 2000:46). In verskeie sektore van die samelewing waar uitnemende prestasies en topgehalte menslike bevoegdheid ' $n$ hoë prioriteit is, word met groot belangstelling na die beweerde terapeutiese motiveringsresultate van NLP gekyk. NLP kan aangewend word vir mense in die ekonomiese en mediese sektore; vir die oriëntering van opleiers van allerlei aard; vir die opleiding van mense wat konfliksituasies moet hanteer en oplos; vir terapie, vir mense wat selfanalises van eie persoonlikheidsituasies moet doen en veel meer. Kortom, in alle sektore waar hoë standaarde en uitnemendheid van gedrag en optrede 'n vereiste is, word gepoog om vas te stel of NLP nie terapeuties kan bydra tot die stimulering van die gewenste uitnemendheid nie. Dit spreek derhalwe vanself dat daar ook in onderwyskringe belangstelling vir NLP ontstaan het en dat onder meer in Nederland en Duitsland gevind is dat daar al op 'n taamlik uitgebreide wyse in 
klaskamersituasies van die NLP-model gebruik gemaak word (vgl. Matzken, 1998:64; Steyn, 1999: 115).

Op grond van 'n vakgerigte literatuurstudie wat oor NLP gedoen is, kan vanuit 'n Christelik-wetenskaplike oortuiging reeds hipoteties gestel word dat die voorstanders/eksponente van NLP hoofsaaklik vanuit ' $n$ psigologiese basis funksioneer. Sommige van die kommunikasietegnieke van NLP sou egter in 'n Christelik deurdagte en gestruktureerde konteks wel met goeie gevolg geïmplementeer kon word. Aangesien egter ook al duidelik uitgewys is dat NLP dikwels gebruik maak van esoteriese tegnieke wat by die spiritisme en die okkulte aanklank vind, is wetenskaplikes in Christelike kringe, soos onder meer Christen-psigo-opvoedkundiges, hieroor verontrus en blyk dit dat NLP nie sonder meer as terapeutiese program aanvaarbaar is nie (vgl. Steyn, 1999:117-118).

Aandag word in hierdie artikel hoofsaaklik toegespits op wat in NLPkringe as "konsepte" of "vooronderstellings" aangedui word. Die ruimte ontbreek om in die algemeen immanent-kritiese en transendentaal-kritiese opmerkings te maak oor soveel verabsoluterings, reduksionismes en humanistiese grondtrekke wat voortspruit uit NLP se affiniteite vir esoteriese spiritisme, gnostisisme, behaviorisme en die talle trekke van die humanistiese dieptepsigologie van Jung en sy geesgenote. ${ }^{1}$ Die kritiese kommentaar wat later in die artikel volg, word daarom slegs toegespits op die aspekte wat in hierdie artikel aangesny word.

Volgens Steyn (1994:27) kan NLP bondig gedefinieer word as "'n subjektiewe waarneming, bestudering, kodering en modellering van uitnemende menslike gedragspatrone". Dit is belangrik om te let op die klem wat NLP-eksponente plaas op terapie as motivering vir uitnemende gedrag. Daar bestaan reeds NLP-institute regoor die wêreld en ook in Suid-Afrika. Alhoewel die NLP-model nog tot onlangs ' $n$ relatief vreemde verskynsel in Suid-Afrika was, word dit volgens Steyn (1999:113, 119), tog toenemend in ons land aangewend deur hoofsaaklik sielkundiges (terapeute) in terapeutiese sessies. Ook privaat onderwysers pas reeds NLP-konsepte toe.

1 Immanent-krities impliseer feitelike kritiek, byvoorbeeld sirkelredenasies; transendentaal-krities impliseer pogings om die teoretiese grondidee wat denkers van die sinverskeidenheid, -totaliteit en oorsprong van alle dinge besit aan te toon, asook die diepste motief wat in hulle denke werksaam is. Vergelyk Schoeman, 1988:80-81 vir meer besonderhede. 


\section{Probleem- en doelstelling}

Hoewel enkele nagraadse studies oor die NLP-model onderneem is en 'n beperkte aantal artikels in dié verband gepubliseer is, is daar nog nie genoegsame navorsing oor NLP in Suid-Afrika gedoen nie. Bewerings dat die NLP-model toenemend deur veral sielkundiges in Suid-Afrika toegepas word, beklemtoon egter dat dit noodsaaklik is dat NLP en sy toepassingsmetodes bestudeer moet word. Aangesien aangeneem kan word dat NLP as beïnvloedings- of motiveringsmodel ook op kinders in die Suid-Afrikaanse terapeutiese konteks toegepas word, is dit noodsaaklik dat die NLPmodel onder meer deur plaaslike Christelike psigo-opvoedkundige navorsers verken, verklaar en beskryf word. Alvorens SuidAfrikaanse sielkundiges en ander persone NLP met gerustheid op kinders kan toepas, behoort Christen-psigo-opvoedkundige navorsers eers 'n grondige ontleding van die belangrikste NLPvooronderstellings en -konsepte te doen.

Die navorsingsprobleem van hierdie artikel kan soos volg geformuleer word:

- Watter vooronderstellings en konsepte vorm die grondslag van die NLP-model?

- In watter opsig het hierdie NLP-konsepte toepassingswaarde vir kinders wat terapie ontvang, asook vir kinders in 'n klaskamersituasie - veral beoordeel vanuit 'n Christelik-wetenskaplike oogpunt?

Die oorkoepelende doel van hierdie artikel is om vanuit 'n Christelike psigo-opvoedkundige perspektief die betekenis, inhoud en relevansie van die hoofkonsepte van die NLP-model te ontleed soos dit moontlik toegepas (kan) word op kinders op weg na volwassenheid.

Vervolgens word eers op enkele algemene opmerkings aangaande NLP gefokus.

\section{Die ontstaan van Neurolinguistiese Programmering}

Die NLP-model het sy ontstaan in die vroeë sewentigerjare te danke aan Richard Bandler en John Grinder. Hierdie grondleggers van NLP het 'n intensiewe studie uitgevoer waarin die werkwyses van drie deskundiges as rolmodelle in die psigologie ondersoek en gemodelleer is. Hierdie drie deskundiges was Milton $\mathrm{H}$. Erickson (hipnoterapie), Virginia Satir (gesinsterapie) en Fritz Perls (gestalt- 
terapie). Uiteindelik is die sogenaamde NLP-model saamgestel wat aanvanklik in psigoterapie aangewend is (O'Conner \& Seymour, 1990:22). Cleveland (1987:viii) stel dat Bandler en Grinder later ook verteenwoordigers uit ander vakgebiede, byvoorbeeld onderwysers wat oor uitnemende gawes beskik het, as rolmodelle gebruik het. Sodoende is die toepassingsmoontlikhede van NLP ook uitgebrei.

\section{Die verband tussen NLP en ander vakgebiede}

Die NLP-model bestaan uit 'n kombinasie van kennis, ervaring en metodes uit uiteenlopende vakgebiede, soos die linguïstiek, neurologie en psigologie wat na bewering tot 'n nuwe en unieke geheel saamgevoeg is (Steyn, 1994:26). Hoewel die juistheid van NLP-bevindings dikwels bevraagteken word, word aanspraak daarop gemaak dat die waarde van die NLP-model veral daarin lê dat dit verskillende soorte teorieë in 'n enkele struktuur saamvoeg. Aangesien hierdie artikel vanuit die gesigshoek van die psigoopvoedkunde aangepak word, sal hoofsaaklik gefokus word op die toepassingswaarde van NLP op kinders wat terapie ondergaan asook op kinders in 'n onderwyssituasie, en wel vanuit 'n Christelikwetenskaplike perspektief.

\section{Uitnemendheid en subjektiewe ervaringstruktuur as fokusgebied en werkobjek van die NLP-praktyk}

In die boek, Neuro-linguistic Programming, Volume I, het die outeurs die volgende verklarende byskrif vir NLP gegee: "The study of the structure of subjectivity" (vgl. Dilts, Grinder, Bandler \& DeLozier, 1980). Die doel met NLP is om 'n beter begrip en handhawing van die mens se subjektiewe ervaring tot stand te bring. NLPeksponente bestudeer dus die struktuur van subjektiewe ervaring en die uitwerking daarvan op menslike gedrag. Die strukturering van ervaring impliseer die ordening van dit wat die mens sien, hoor en voel. Die strukturering van subjektiewe ervaring hou ook verband met die wyse waarop kinders en volwassenes dit wat hulle sien, hoor en voel in taal (woorde) beskryf en hoe daar, intensioneel sowel as nie-intensioneel, te werk gegaan word om resultate te verkry (Dilts et al., 1980:i; O'Conner \& Seymour, 1990:23).

NLP bied klaarblyklik 'n model waardeur aangeleer kan word om uitnemendheid in persone te herken en hoe om te werk te gaan om ander mense bewus te maak van die aspekte waaruit hierdie uitnemendheid bestaan, sodat hulle dit in hulle lewens kan toepas (Bodenhamer \& Hall, 1999:xii). Hiervolgens kan onderwysers wat byvoorbeeld hul onderrig wil verbeter, ander uitnemende onder- 
wysers as rolmodelle gebruik. Johnston (1998:6) stel dat NLP "has a vision of a world in which there is no shortage of excellence and where education is about helping everyone to be outstanding". In hierdie oordrewe optimisme om in 'n wêreld van gedifferensieerde vermoëns en verskillende vlakke van aanleg, bevoegdhede en bekwaamheid terapeuties by die toppunt van uitnemendheid van elke persoon uit te kom, ontdek 'n mens, immanent-krities beskou, 'n anomalie. Dit is teenstrydig met die werklikheid van menswees om aan te voer dat alle mense (individuele persoonlikhede) latent tot dieselfde vlak van uitnemendheid in staat is. Kritiese kommentaar op hierdie aspek volg in afdeling 9.

\section{Vooronderstellings van die Neurolinguistiese Program- meringsmodel}

\subsection{Wat is "vooronderstellings"?}

NLP-grondleggers en -aanhangers beskou NLP nie werklik as 'n teorie nie, maar eerder as 'n model. Die NLP-model beklemtoon hoofsaaklik die aspekte van modellering, eksperimentering en toetsing, in teenstelling met teoretisering en hipotetisering. Hierdie uitgangspunt ten spyt, bly dit egter ' $n$ feit dat die praktyk (soos ook by die NLP-model) deur onderliggende teorieë bepaal en gerig word. Tersaaklike vakliteratuur oor NLP toon dat die beste wyse waarop NLP verstaan kan word, is om dit self te ervaar. Waar ' $n$ teorie ' $n$ hipotese impliseer wat poog om die redes te verduidelik waarom dinge met mekaar verband hou, is ' $n$ model 'n patroon of nabootsing van reeds bestaande verskynsels wat (soos dit ontwerp is) nageboots of herskep kan word. ' $n$ Model het slegs te make met dít wat waargeneem kan word (Zastrow, Dotson \& Koch, 1987:30; Zastrow, 1992:484).

In aansluiting by die probleemstelling van hierdie artikel (vgl. afdeling 2), kan verklaar word dat die NLP-model tog op verskeie vooronderstellings berus. Hall (1996:77) omskryf vooronderstellings soos volg: "presuppositions consist of all those essentials required for a statement to make sense in a person's reality". Dit is in 'n sekere sin verblydend dat voorstanders van die NLP-model die onvermydelikheid van bepaalde vooronderstellings as noodsaaklik vir die begronding van hul teorieë beskou. Die transendentaalkritiese vraag vir Christenwetenskaplikes sou egter wees watter religieuse grondmotiewe die basis van die vooronderstellings vorm. Die Christenwetenskaplike stel belang in die besondere wysgerige vertrekpunte vir die implementering van NLP. Dit bly 'n vraag of onder Hall se kort omskrywing van "presuppositions" as die 
essensiële vereistes wat die sin van die werklikheid impliseer, dieselfde verstaan word as wat die Christenwetenskaplike onder vooronderstellings verstaan. Christenwetenskaplikes is daarop bedag om vooronderstellings te tipeer en te hanteer as grondvrae aangaande die wortel van wetenskaplikes se grondoortuigings oor hulle bepaalde kosmologiese totaliteits- en oorsprongidee. Trouens, sodanige vooronderstellings is gevestig op die strukturele voorwaardes wat alle teoretiese denke oor dinge moontlik maak (vgl. Strauss, 1988:44; vgl. kommentaar by afdeling 9).

NLP-vooronderstellings is op teoretiese grondslae gebaseer wat gevind word in sisteme wat gemodelleer is, naamlik onder andere die gestaltpsigologie (Perls), gesinsisteemterapie (Satir), Ericksoniese hipnoties-mediese kommunikasie, algemene semantiek (betekenisleer), inligtingsisteme, transformasionele grammatika en kognitiewe gedragspsigologie (Bodenhamer \& Hall, 1999:63). Die belangrikste vooronderstellings van die NLP-model, soos aangedui deur NLP-skrywers, word voorts kortliks behandel.

\subsection{Vooronderstellings aangaande die verwerking van persepsies}

- Daar is 'n verskil tussen die wêreld self en die wyse waarop mense die wêreld beleef. In navolging van Korzybski (1958:750) berus die NLP-model op die vooronderstelling dat "die 'kaart' nie die gebied is nie". Hieruit volg dat daar 'n verskil bestaan tussen die wêreld self en die wyse waarop mense die wêreld beleef (hulle modelle, "kaarte" of innerlike voorstellings van die wêreld) (vgl. afdeling 7.2). Hierdie siening is geensins iets nuuts nie, maar bevat algemeenhede wat voorgehou word as deel van die volwaardige teorie waarop die NLP-model berus.

- Elke persoon se besondere wêreldmodel moet gerespekteer word: Aangesien persone volgens hulle eie "kaarte" funksioneer, sal hulle inligting op 'n eie unieke wyse verwerk. Innerlike voorstellings sal gevolglik van persoon tot persoon verskil (Bodenhamer \& Hall, 1999:75). Hierdie vooronderstelling berus op 'n blote gemeenplaas, want dit is 'n algemeen bekende feit dat mense verskil.

- Ervaring beskik oor struktuur: Indien die struktuur van 'n individu se ervaring onderskei kan word, kan die struktuur (en gepaardgaande hiermee die ervaring self) verander word (Alder, 1996:28). Die konsep struktuur hou, soos reeds vermeld is, verband met die ordening en verwerking van wat deur sien, hoor en voel subjektief ervaar word. 
- Indien een persoon iets kan doen, kan enige persoon leer om dit te doen: Volgens Andreas en Faulkner (1998:35) hou dié idee in dat elke persoon van die vooronderstelling moet uitgaan dat alles moontlik is. Hierdie beskouing is een van die NLP-vooronderstellings wat deur sommige (hoofsaaklik Christen-) navorsers bevraagteken word. Hierdie onrealistiese optimisme oor die mens se vermoëns word derhalwe met skeptisisme benader. Dié vooronderstelling wat die NLP-model onderlê, is 'n voorbeeld van die feit dat NLP op onrealistiese aannames oor die mens en menslike vermoëns berus. Hierdie aannames korreleer naamlik nie met die werklikheid en met skeppingsgewens nie. Die deurwerking van die humanistiese vryheidsideaal word in bogenoemde aannames bespeur.

- Mense reageer in ooreenstemming met hulle innerlike voorstellings: Na aanleiding van die kaart-/gebiedonderskeiding, bepaal en beheer mense se "kaarte" (soos oortuigings, taal, herinneringe) hulle persepsies en reaksies. Individue, so word beweer, reageer op die wêreld, nie soos dit werklik bestaan nie, maar volgens hul innerlike voorstellings daarvan (Bodenhamer \& Hall, 1999:67-68). Voordat daar byvoorbeeld van kinders verwag kan word om hulle denke, emosies of reaksies te verander, moet hul innerlike voorstellings ("kaarte") eers verander.

- Liggaam en gees beïnvloed mekaar: In navolging van die gestaltterapie se holistiese beskouing van die mens, kan binne die raamwerk van die NLP-model gestel word dat gedagtes en liggaam onderling deel is van dieselfde biologiese sisteem en dat hulle mekaar wedersyds beïnvloed (Derks \& Hollander, 2000:25).

- Individuele vaardighede funksioneer deur die ontwikkeling en opeenvolging van voorstellingsisteme: Die wyse waarop mense hulle voorstellingsisteme in hul handelinge en denke gebruik, lei tot die ontwikkeling van hul vaardighede. Die menslike verstand verkry nie alleen inligting deur die sintuie nie, maar verwerk en berg dit ook. Hierdie inligting (beelde, klanke, gevoelens en reuke) word dan gebruik om vaardighede te ontwikkel, wat dit weer moontlik maak om handelinge uit te voer (Bodenhamer \& Hall, 1999:72).

\subsection{Vooronderstellings aangaande menslike gedrag/reaksies}

- Mense en hul gedrag kan as verskillende verskynsels beskryf word (mense is méér as hul gedrag): Mense se gedrag bepaal nie hul aard nie, maar dit weerspieël byvoorbeeld net hulle norme en waardes (Bodenhamer \& Hall, 1999:76). 
- Alle gedrag is nuttig in 'n spesifieke konteks: In die NLP-konteks word met hierdie uitspraak geïmpliseer dat daar onderliggend aan enige gedragswyse 'n positiewe bedoeling of doel is (Mackenzie, 1984:127).

- Gedrag en verandering word geëvalueer in terme van konteks en ekologie: Rooney (soos aangehaal in Bodenhamer \& Hall, 1999: 78) stel dat ekologie na die volgende verwys: "the concern that any changes made at one point in a human system must be compatible with and adaptable to the other parts of the system". Die uitgangspunt dat 'n persoon se gedrag nie in 'n vakuum voorkom nie, maar in 'n sisteem van byvoorbeeld handelinge, idees en gevoelens, is ' $n$ algemene beskouing wat deur alle bevoegde terapeute erken word.

\subsection{Vooronderstellings aangaande kommunikasie}

Baie van die onderstaande vooronderstellings aangaande doeltreffende kommunikasie, wat klaarblyklik die grondslag van NLP vorm, kom daarop neer dat die algemeen bekende stand van sake in terapie aanvaar word. Hierdie bevindings kan nie as unieke, nuut ontdekte aangeleenthede beskou word nie.

- Daar kan nie nie gekommunikeer word nie: Kommunikasie behels dat ' $n$ "boodskap" aan iemand anders gestuur word. Selfs wanneer persone nie hulle gedagtes, gevoelens, idees, oortuigings of besluite in woorde omsit nie, kommunikeer hulle dit op verskeie nieverbale wyses aan ander (Andreas \& Faulkner, 1998:36).

- Die wyse waarop gekommunikeer word, beïnvloed persepsie en resepsie (ontvangs): Daar word nie slegs gekommunikeer deur wat gesê word nie (verbaal), maar ook deur hoe iets gesê word (die nieverbale aspekte, soos stemtoon, gesigsuitdrukkings en houding) (Bodenhamer \& Hall, 1999:79). Enige bevoegde sielkundige sal hiermee saamstem. Tog wil dit voorkom asof die betekenis van nieverbale kommunikasie in NLP-kringe ietwat oordryf word.

- Die betekenis van enige kommunikasie lê in die reaksie wat dit uitlok (ongeag die bedoeling van die mededeler): Persone moet in gedagte hou dat hulle in hul kommunikasie met ander persone moontlik één ding bedoel, maar dat ander dit nie altyd so verstaan nie (Johnston, 1998:6).

- Daar bestaan geen mislukking nie, slegs terugvoering (Alder, 1997:17-18): Die NLP-siening wat gehuldig word, is dat dít wat 
gebeur, nie as goed of sleg beskou moet word nie, maar dat dit hoofsaaklik as inligting gesien moet word. Mense benodig inligting of terugvoering om hulself te verbeter. Vanuit 'n Christelik-wysgerige perspektief oor die mens se geneigdheid tot sonde impliseer hierdie aanname dat reaksies nie as goed of sleg getipeer moet word nie, 'n onrealistiese optimisme. Trouens, weens die sondeval is mislukking ook onvermydelik deel van die menslike lewe op aarde (vgl. kommentaar by afdeling 9).

- Die persoon met die meeste buigsaamheid oefen die meeste invloed op die sisteem uit en sal meer keuses uitoefen en die beste kans op sukses hê. Hoe meer keuses persone het, hoe beter sal hulle 'n probleem kan oplos (Dilts \& Green, 1982:223). Indien dit wat onderwysers doen, byvoorbeeld nie die gewenste uitwerking op hul leerders het nie en hulle hul leerders moontlik verveel, moet onderwysers hul gedrag verander totdat hulle suksesvol is.

\subsection{Vooronderstellings by leerkeuse-veranderings}

Volgens die voorstanders van NLP het elke mens reeds die nodige innerlike hulpbronne (soos herinneringe, gevoelens, gedrag) om enige verlangde doelwit te bereik, enige situasie te hanteer en enige verlangde verandering te bewerkstellig: Met behulp van NLP kan mense gelei word om bewus te word van hulle innerlike bronne en hoe om dit te orden (Derks \& Hollander, 2000:125). Dit wil voorkom asof met hierdie aannames vrylik veralgemeen word, en persone wat van NLP gebruik maak, baie onrealistiese en optimistiese vooronderstellings aangaande die mens en menslike vermoëns het. Een van hierdie vooronderstellings is dat enige verlangde doelwit bereik kan word. Weens die beperkte vermoë van die mens - in teenstelling met God se almag - word hierdie vooronderstelling ook deur die Christenwetenskaplike bevraagteken.

Wanneer persone handelinge uitvoer, gebruik hulle die beste keuses wat hulle op daardie stadium tot hulle beskikking het. Indien beter keuses beskikbaar sou wees, sou persone dit tog gebruik het (Blackerby, 1996:80). Hierdie vooronderstelling van NLP dui ook op ' $n$ veralgemening. As voorbeeld kan geneem word dat bevoegde onderwysers behoort te weet dat ongewenste gedrag, soos frustrasie by leerders wat byvoorbeeld probleme met die oplossing van wiskundeprobleme ondervind, die mees waarskynlike keuse van gedrag vir leerders op dié tydstip sou wees. 


\section{Belangrikste konsepte onderliggend aan die NLP- model}

Met die voorafgaande NLP-vooronderstellings as grondslag, word die hoofkonsepte waarop die NLP-model basies berus, vervolgens bespreek. Daar sal gepoog word om (ter beantwoording van die tweede probleemvraag waarop hierdie artikel berus) telkens die praktiese toepassingswaarde van hierdie NLP-konsepte uit te wys. Die toepassingswaarde sal vanuit 'n Christelik-wetenskaplike perspektief aangetoon word ten opsigte van kinders wat terapie ondergaan asook ten opsigte van kinders in 'n klaskamersituasie.

\subsection{Modellering}

'n Model is 'n vereenvoudigde beskrywing van 'n komplekse entiteit of proses. Hierdie term is afkomstig van die Latynse stam modus, wat 'n wyse van doen beteken, dit wil sê 'n metode, vorm, wyse, patroon, gewoonte of 'n styl. Die woord model en dus ook modellering, is meer spesifiek afgelei van die Latynse modulus wat 'n '"small' version of the original mode" impliseer (Dilts, 1998:28). Volgens Hall en Bodenhamer (1999:4) sluit modellering as NLPkonsep die proses in waardeur suksesvolle, uitnemende handelinge en gedrag van ander persone waargeneem en as model nageboots word. Hiervolgens kan leerders wat byvoorbeeld 'n besondere vermoë het om te spel, dus as modelle gebruik word.

Dilts (1998:29) verklaar dat NLP-modelleringsprosedures gebruik kan word om uit te vind hoe die brein (neuro) funksioneer, deurdat taalpatrone (linguistiese) en nieverbale kommunikasie ontleed word. Die resultaat van hierdie ontleding word dan omgesit in stap-virstapstrategieë of programme (programmering) wat gebruik kan word om, in ooreenstemming met 'n opvallend optimistiese bewering, feitlik enige vaardighede aan ander persone oor te dra. Byna soos ' $n$ refrein ontdek 'n mens deurgaans in die antropologiese momente van die NLP-eksponente se beskrywings hierdie oordrewe optimisme. Volgens hierdie uitgangspunt en veralgemening sou alle kliënte tot 'n gelyke mate van uitnemende bevoegdheid gebring kon word. Deur modellering binne die NLP-model toe te pas - 'n werkswyse wat skynbaar gelykgestel word met die begrip programmering - word beweer dat letterlik enige vaardigheid en gedragswyse aan persone "oorgedra" kan word. Modellering word wel in sommige gevalle in enige oordeelkundige terapieproses gebruik. Terapeute sal byvoorbeeld van handpoppe gebruik maak om aan kleuters te demonstreer hoe om respek vir hulle meerderes te toon. (Verdere kritiese kommentaar volg in afdeling 9.) 


\subsection{Voorstellings (modelle) van die wêreld}

Elke mens (kind sowel as volwassene) funksioneer volgens NLPeksponente op grond van 'n model of "kaart" ('n voorstelling) van wat geglo word wat die wêreld is. Mense interpreteer alles wat rondom hulle gebeur op 'n unieke wyse deur hul sintuie (Grinder \& Bandler, 1976:4; Alder, 1997:13). Dilts en Green (1982:216) verklaar dat hierdie voorstellings wat mense gebruik om hulle ervarings van die wêreld te orden, egter nie die wêreld self is nie, maar dat dit neurologiese transformasies is wat akkuraat of selfs nie-akkuraat kan wees ("die kaart is nie die gebied nie" vgl. 6.2).

In die ordening van die mens se sintuiglike indrukke en herinneringe in 'n samehangende wêreldmodel, onderskei aanhangers van NLP drie belangrike modelleringsbeginsels, naamlik weglatings, vervormings en veralgemenings. Die modelle wat die mens skep, sal dus in hierdie drie opsigte van die werklike wêreld verskil, asook van ander persone se wêreldmodelle (Bandler \& Grinder, 1975a:7-8; 1975b:11; Kruger, 1999:79; Derks \& Hollander, 2000:56-57). Cleveland (1987:19) verklaar dat ook kinders se unieke ervarings aan hulle hulle eie persepsies/modelle van die werklike wêreld verskaf. As voorbeeld kan gestel word dat twee kinders verskillende persepsies/modelle kan hê aangaande 'n glas wat half met water gevul is. Die een kind mag byvoorbeeld sê dat die glas halfvol water is, terwyl die ander kind kan sê dat dieselfde glas halfleeg is.

In tersaaklike NLP-vakliteratuur blyk dit dat die voorstanders van hierdie model glo dat húlle tot die belangrike gevolgtrekking gekom het dat 'n deeglike begrip van hoe kinders (en volwassenes) voorstellings skep van die wêreld waarin hulle woon, tot voordeel sal strek van elke sielkundige, maar ook elke onderwyser in die klaskamersituasie. In teenstelling hiermee kan gestel word dat enige bevoegde terapeut of onderwyser dit noodsaaklik sal ag om te alle tye te poog om te verstaan hoe kinders dink (met ander woorde om die paradigma van waaruit hulle funksioneer af te lei) en dit byvoorbeeld as vertrekpunt in terapie of onderrig te gebruik.

\subsection{Die metamodel in psigoterapie}

Die metamodel bestaan uit ' $n$ aantal taalonderskeidings wat taalpatrone, waarvan die betekenis in die kommunikasieproses vertroebel is op grond van weglatings, vervormings en veralgemenings, identifiseer. Sodanige identifiseringsproses impliseer 'n uitdaging, naamlik om dit te bewerkstelling dat die "swak geformuleerde" taaluitings weer aansluit by sensoriese ervaring en 
die dieptestruktuur van die voorafgaande taaluiting (Bodenhamer \& Hall, 1999:394). Bandler en Grinder (1975a:40-53, 59-107) gaan in besonderhede in op die oorspronklike terapeutiese metamodel. Die NLP-metamodel is deur Bandler en Grinder ontwikkel om die ware betekenis van 'n persoon se kommunikasie af te lei deur hierdie drie elemente, naamlik die swak geformuleerde taaluiting, die sensoriese ervaring en die dieptestruktuur van die taaluiting te ondersoek (Alder, 1997:160). Volgens Bodenhamer en Hall (1999:34, 394) is die woord meta afgelei van 'n Griekse woord wat bo(kant), buite, van en op 'n hoër vlak beteken. Die metamodel van NLP is meta (op 'n hoër vlak) ten opsigte van wêreldmodelle; dit is 'n eksplisiete model vir die verandering van wêreldmodelle.

Alhoewel Bandler en Grinder aanvanklik gepoog het om 'n volledige, formele taaluitruilingsmodel in psigoterapie (met kinders en volwassenes) te ontwikkel, skyn dit asof die metamodel ook later op terreine soos die onderwys toegepas is (Bandler \& Grinder, 1975b: $8,10)$. Volgens Bandler en Grinder is dit noodsaaklik dat sielkundiges (en ook ander persone soos onderwysers) sal besef dat elke sin van elke taal twee onderskeie voorstellings verteenwoordig: die voorstelling van hoe dit werklik klink, bekend as die oppervlaktestruktuur, asook die voorstelling van die betekenis daarvan, naamlik die dieptestruktuur (Knight, 1996:45). Wanneer 'n kind byvoorbeeld sê: "Die glas het gebreek", is die oppervlaktestruktuur die voorstelling van die werklike klanke wat deur die kind gesê word. Die dieptestruktuurbetekenis hiervan is dat afgelei kan word dat hierdie voorval in die verlede plaasgevind het: dit was 'n komplekse gebeurtenis en die aksie "breek" het plaasgevind tussen die agent, die objek wat gebreek is en die instrument wat gebruik is om die glas te breek. Die hele proses wat 'n dieptestruktuur met die oppervlaktestruktuur verbind, word 'n afleiding genoem (Bandler \& Grinder, 1975b:8-9, 218-219; Grinder, DeLozier \& Bandler, 1977:5657). Sommige inligting gaan dus verlore in die transformasie van die dieptestruktuur na die oppervlaktestruktuur.

Met behulp van die uitdaging van bogenoemde drie modelleringsprosesse beweer NLP-eksponente dat kinders wat terapie ondergaan asook kinders in 'n skoolsituasie deur middel van die NLP-metamodel gelei kan word om in die meeste gevalle, indien nodig, hulle wêreldmodelle heeltemal te verander. Kosmologies en antropologies kan in terme van 'n realistiese beskouing van die werklikheid en van menswees egter krities gevra word of die verandering van modelle werklik so maklik haalbaar kan wees. Om 'n paradigmaverskuiwing te ondergaan, is geensins so 'n vinnige en maklike proses as wat NLP-eksponente beweer nie. In hierdie 
proses moet die diepste oortuigings waarop mense hulle lewens rig, verander voordat hulle wêreldmodelle en hul gepaardgaande gedrag en gesindhede uiteindelik kan/sal verander.

\subsection{Voorstellingsisteme}

Alle ervarings van die mens is volgens NLP-opvattings saamgestel uit die boustene van sensoriese ervarings. Wanneer mense inligting aangaande die wêreld om hulle verwerk, word dit in terme van die vyf sensoriese (sintuiglike) sisteme of ervaringsmodaliteite gekodeer: die visuele (sien - oë), ouditiewe (hoor - ore), kinestetiese (voel - vel), olfaktoriese (ruik - neus) en smaaksisteme (proe tong) (Andreas \& Andreas, 1992:14). Aangaande die verwerking van sintuiglike inligting word dus slegs op die benedestrukture van die menslike liggaamstruktuur gefokus (vgl. kommentaar by afdeling 9).

Indien krities op die begrip voorstellingsisteem as NLP-term gelet word, blyk dit dat dit slegs 'n ekwivalent is vir die alombekende feit dat die mens inligting op spesifieke wyses verwerk. Volgens NLPoortuiging word die visuele, ouditiewe en kinestetiese sisteme as die primêre voorstellingsisteme gebruik om komplekse inligting te ontvang en te interpreteer (O'Conner \& Seymour, 1990:44; Andreas \& Andreas, 1992:14; Robbins, 1997:127). Mense maak op hul voorstellingsisteme staat om inligting van die eksterne wêreld in te samel, te berg en te kodeer. Dit moet egter genoem word dat laasgenoemde feite eintlik maar bestaande gemeenplase ("common sense") is wat geensins deur NLP-eksponente nuut ontdek is nie. Dit wil voorkom asof NLP-eksponente reeds bestaande inligting aanwend en as nuut ontdekte insigte verkondig.

Die NLP-model konsentreer dus ook met betrekking tot kommunikasie (verbaal en nieverbaal) op die mens as "perseptuele wese" deurdat persepsies in visuele, ouditiewe en kinestetiese modaliteite gedefineer word. Om persepsies tot hierdie modaliteite alléén te reduseer, is strydig met die Reformatoriese kosmologiese en antropologiese denkraamwerk en lei tot reduksionisme waardeur die mens tot 'n "perseptuele wese" gereduseer word (vgl. kommentaar by afdeling 9). Vanuit 'n Christelik-wetenskaplike perspektief moet die mens gesien word as 'n skepping van God; iemand wat as 'n geheel funksioneer.

Die NLP-model is voorts gebaseer op die feit dat die meeste mense oor 'n primêre voorstellingsisteem (PVS) beskik, wat (onbewustelik) meer as enige ander sisteem gebruik word om in sekere situasies hul ervarings te orden (Grinder \& Bandler, 1976:9). 
Voorstellingsisteme hou ook verband met verskillende leerstyle en is gevolglik betekenisvol vir klaskamerleer. Leerteorieë stem ooreen dat leerders moet sien, hoor en ervaar wat hulle leer. Indien onderwysers bewus is van hulle eie primêre voorstellingsisteem, sowel as van dié van hul leerders, word beweer dat klaskamerkommunikasie sal verbeter (Johnston, 1998:7; Steyn, 1999:116). Daar word voorgestel dat onderwysers (in aansluiting by die NLPvooronderstelling dat soepelheid 'n vereiste vir sukses is; vgl. 6.4) 'n onderwysmodel gebruik wat al drie die voorstellingsisteme insluit om sodoende te verseker dat alle leerders optimaal leer. Indien onderwys ' $n$ multisensoriese ervaring is, sal dit interessanter wees en ook voorsiening maak vir elke leerder se voorkeur deurdat van al die voorstellingsisteme gebruik gemaak word. Sogenaamde "stadige" leerders leer dikwels net anders en vind dat die huidige onderwysstyl nie vir hulle voorsiening maak nie (Waldheim, 1987: 307; O'Conner \& McDermott, 1996:67). Tans word al hoe meer in die onderwys gekonsentreer op die feit dat die leerstyle van leerders in ag geneem moet word en daar bestaan verskeie leerstylteorieë in hierdie verband. Bogenoemde sogenaamde NLP-siening aangaande leerstyle is niks nuuts of unieks nie, maar is gebaseer op reeds bestaande leerstylteorieë.

Volgens Woerner en Stonehouse (1988:522) is een van die waardevolle NLP-strategieë om kinders te help om reeds op 'n vroeë ouderdom 'n vermoë te kweek om maklik toegang tot al die modaliteite te ontwikkel, asook om daartussen te kan beweeg. Aktiwiteite in elk van die voorstellingsisteme is gekoppel aan verskillende waarneembare reaksies, met ander woorde, sielkundiges kan byvoorbeeld aan die "buitekant" van kinders sien watter innerlike voorstellingsisteme hulle op 'n gegewe moment gebruik. Wanneer ouditiewe leerders byvoorbeeld aan 'n nuwe situasie blootgestel word, praat hulle normaalweg daaroor, terwyl kinestetiese leerders die nuwe situasie deur middel van manipulasie ondersoek (vgl. Cleveland, 1987:30-31).

\subsubsection{Predikate en toegangsaanduidings}

NLP gaan van die vooronderstelling uit dat persone se primêre voorstellingsisteem onbewustelik op subtiele wyses deur hulle verbale en nieverbale gedrag weerspieël word (Williams \& Jacobson, 1989:454, 455). (Verbale gedrag is in NLP bekend as predikate, byvoorbeeld die gebruik van byvoeglike naamwoorde en werkwoorde in 'n taaluiting. Nieverbale gedrag kom weer na vore deur onder andere byvoorbeeld oogbewegings, asemhalingstempo en liggaamshouding). 
Bester et al. (2000:48) verklaar dat daar 'n duidelike verband is tussen die waarneembare aspekte van gedrag (verbaal en nieverbaal) en die patrone van neurologiese aktiwiteite wat gedrag rig. Bandler en Grinder (1975b:10-11) voer aan dat persone met 'n persoonlike voorstellingsisteem wat byvoorbeeld visueel is, hulle ervarings met woorde soos "sien", "kyk", "waarneem", ensovoorts sal beskryf. Hierdie tipe terminologie veronderstel 'n visuele sisteem. Dieselfde sal geld vir persone wat oorwegend ouditief, kinesteties, reuk- of smaakgeoriënteerd is. Mense baseer egter nie net hul ervarings op verskillende voorstellingsisteme nie, maar ook op hul kommunikasie. Bodenhamer en Hall (1999:5) verklaar dat bogenoemde ook inhou dat onderwysers wat byvoorbeeld inligting voor 'n klas weergee, daarop moet let dat hulle al drie die belangrikste voorstellingsisteme in hul aanbiedings gebruik. Indien onderwysers byvoorbeeld die meeste dinge ouditief kodeer, sal hulle moontlik (onbewustelik) ouditiewe terminologie soos "hoor", "luister", "vertel", ensovoorts gebruik en hierdie tipe kommunikasie sal slegs by 'n persentasie van die leerders aanklank vind. Op hierdie wyse sal leerders wat inligting hoofsaaklik visueel of kinesteties verwerk, uitgesluit word.

Gepaardgaande met die bewustheid van 'n persoon se woordgebruik, word ander aanduidings of gedrag ook in NLP gebruik om 'n persoon se voorstellingsisteem af te lei, naamlik toegangsaanduidings (-tekens of -seine). Hierdie aanduidings dui aan tot watter voorstellingsisteem 'n persoon op 'n spesifieke tydstip toegang het (Bodenhamer \& Hall, 1999:17-18).

Die toegangsaanduidings wat klaarblyklik volgens die NLPeksponente die maklikste waargeneem kan word, is oogbewegings. Volgens hierdie aanname sou mense dus hul oë in sekere rigtings beweeg - afhangende van hul spesifieke denkwyses. Hierdie oogbewegings staan in NLP-terme bekend as oogtoegangsaanduidings (Alder, 1997:59). Die volgende vraag dien as voorbeeld om bogenoemde te verduidelik: "Wat was die kleur van die kersies op jou verjaarsdagkoek toe jy ses jaar oud was?" Indien hierdie tipe vraag byvoorbeeld aan kinders gestel word, word beweer dat die meerderheid opwaarts en na hul linkerkant sal kyk. Die linkerkant is die kant waar regshandige, en sommige linkshandige persone toegang tot visuele beelde verkry (Robbins, 1997:127). Die "lees" van nieverbale gebare of tekens word in NLP oorbeklemtoon. Alhoewel daar sekerlik definitiewe, kultureel bepaalde wyses van nieverbale kommunikasie bestaan, kan die uitgangspunt dat alle nieverbale gebare of tekens dieselfde betekenis vir alle mense het, bevraagteken word. Alle nieverbale gebare is ook nie noodwendig 
altyd wyses van bewustelike of onbewustelike kommunikasie nie. Dié feit alleen veroorsaak al 'n mate van skeptisisme, sekerlik by meer wetenskaplikes as slegs diegene wat vanuit 'n Reformatoriese denkraamwerk die werklikheid en die mens bestudeer.

Die feit dat NLP-eksponente daarop aanspraak maak dat hulle, deur persone se oogbewegings waar te neem, onmiddellik kan aflei watter voorstellingsisteme hulle op 'n spesifieke tydstip gebruik, is moeilik verifieerbaar en klink op die oog af ietwat vergesog. Veral diegene wat mens en werklikheid vanuit 'n Reformatoriese denkraamwerk bestudeer, sal eers op grond van waterdigte, wetenskaplik verantwoordbare antropologiese en kosmologiese bewysgronde so iets kan aanvaar, sonder om daarmee die positivisme ten prooi te val. Aan die ander kant kan 'n mens ook nie sekere sielkundige oortuigings/sienings met beslistheid bloot net "afskiet" nie. 'n Mens kan hoogstens krities na meer bewysgronde vra.

\section{Gevolgtrekkings}

Die eerste probleemstellende taak van hierdie artikel behels die verduidelikende uiteensetting van vooronderstellings wat die eksponente van die NLP-model as grondslag daarvoor aandui. In die artikel is dus gepoog om die tersaaklike vooronderstellings uiteen te sit. Die gevolgtrekking kan gemaak word dat die vooronderstellings en konsepte onderliggend aan die NLP-model nie uniek is nie, maar gegrond is op bestaande terapeutiese beginsels wat aangepas is en selfs op gemeenplase wat só gestruktureer is dat dit aan NLP die skynvoorkoms van 'n nuwe terapeutiese program bied. Hoewel die grondleggers van NLP erken het dat hulle van bestaande teorieë, psigoterapeutiese konsepte en taalkundige beginsels gebruik gemaak het, beweer hulle tóg dat dit op 'n nuwe en unieke wyse georden is om sodoende die NLP-model te vorm.

In 'n poging om die tweede probleemvraag in die gestelde probleemstelling te beantwoord, is die toepassingswaarde (indien enige) van NLP-konsepte op kinders, hetsy terwyl hulle terapie ondergaan of in 'n gewone skoolsituasie is, deurgaans vanuit psigoopvoedkundige perspektief belig. Die gevolgtrekking kan op hierdie stadium gemaak word dat dit skyn asof NLP-konsepte nie met gerustheid deur die Christen-onderwyser of -sielkundige op kinders toegepas kan word nie. Dit wil voorkom asof algemeenhede slegs op 'n lukraak wyse binne die NLP-model geïntegreer is sonder dat dit goed nagevors of wetenskaplik voldoende geartikuleer is. 


\section{Enkele kritiese kanttekeninge aangaande NLP}

Ter aanvulling van kommentaar wat reeds gelewer is in die loop van hierdie artikel, nog enkele opmerkings met verwysing na perspektiewe rondom die bespreking van vooronderstellings en konsepte. Omdat hierdie artikel konsentreer op dit wat as wetenskaplike vooronderstellings en konsepte deur voorstanders van NLP voorgehou word, is die volgende vrae belangrik vir Christen-psigo-opvoedkundiges wat wetenskap beoefen vanuit 'n Reformatoriese denkraamwerk: Watter religieuse grondmotief (grondmotiewe) of dryfkrag begrond die NLP-denke as voorteoretiese voorwaardes vir hul denke? Watter wetsidee onderlê hulle denkpatroon, met ander woorde openbaar hulle insig ten opsigte van die verrekening van 'n volledige sinverskeidenheid, -samehang en -totaliteit wanneer hulle die mens (antropologies) en die werklikheid (kosmologies) onder die loep neem, of reduseer hulle die mens en werklikheid tot 'n parsiële, skeefgetrekte onvolledigheid? In die beredenering wat NLP onderlê, skyn dit ook of daar bevraagtekenbare teenstrydighede is wat immanent-krities aangedui kan word. Daar is byvoorbeeld meermale daarop gewys dat verskille tussen persone ten opsigte van terapeutiese prosedures enersyds in ag geneem word, maar dat die verskille andersyds genegeer word as die NLP-eksponente voorhou dat alle mense tot dieselfde mate van uitnemendheid van gedrag en prestasie gelei of gemotiveer kan word (vgl. afdeling 6.2 en elders).

In afdeling 6.2 is aangedui dat, volgens Derks en Hollander (2000:25), gedagtes (logiese aspek) en liggaam (bedoelende die natuurkaders) deel is van dieselfde "biologiese sisteem" (biotiese aspek) en mekaar wedersyds beïnvloed. So word die biotiese aspek tot grondnoemer van die aspekteverskeidenheid verhef en die mens gereduseer tot "biotiese organisme". Verder word die mens se bestaan en ervarings reduksionisties oor die boeg van die werking van die sintuie gegooi. Pogings om via die gestaltterapeutiese, holistiese, antropologiese grondslae tot 'n totaliteitsbeskouing aangaande die mens te kom misluk, omdat NLP in wese 'n humanistiese beklemtoning het waarin die mens gesien word as "biologiese sisteem", en as "psigiese wese" waarby ervaring en gedrag onder die primaat staan van die mens se sintuie. Dit skyn dus asof NLP se humanistiese uitgangspunte mank gaan aan verabsoluterings en reduksionismes wat dui op 'n gebrek aan volledige modale onderskeidingskennis en op 'n parsiële samehangsidee. 
Menslike gedrag word veelal deur die aanhangers van NLP op 'n eie wyse oor die boeg van behavioristiese opvattings gegooi. Gedrag word sodoende nie vertolk as 'n integrale, interne deel van die persoonlikheid nie, maar word saam met norme en waardes dualisties as 't ware gesien as iets wat van buite af en onder primaat van stimuli op die persoonlikheid se sintuie inwerk.

NLP-eksponente se houding dat daar nie so iets soos mislukkings bestaan nie, dat mislukking slegs 'n vorm van terugvoering is, herinner aan die romantisistiese naturalisme van J.J. Rousseau met sy leer dat die mens goed gebore is. Die NLP-teorie openbaar veelal die deurwerking van die natuur-vryheid-grondmotief, soms met klem op die natuurpool (daar word gedurig reduksionisties klem gelê op die mens se sintuie). Dat mislukkings nie goed of sleg sou wees nie, maar bloot as terugvoering gesien moet word, stel die mens onder primaat van die humanistiese vryheidsideaal algeheel vry van enige sondeskuld. Die implikasie van hierdie gedagte dat mislukkings wat onder meer vanweë "sondige" neigings voorkom, byvoorbeeld die neiging van versuim of wat ook al, blote terugvoering is en nie die uitkoms van 'n mens se onverantwoordelike optrede nie, illustreer die deurwerking van die humanistiese vryheids- of persoonlikheidsideaal. 'n Mens vind ook iets van die gnostiese denke in hierdie siening. Die gnostiek het die mens naamlik getipeer as 'n afsplitsing van die godheid met 'n potensieel (gewaande) selfstandige denke wat net wag om geaktiveer te word. So vind 'n mens vanuit enige vorm van die humanistiese benaderings van wetenskap en praktyk, waarvan die NLP-teorie en -terapeutiese praktyk deel is, altyd 'n wisselwerking tussen die natuur- en vryheidspole van die humanistiese religieuse grondmotief.

Vanuit 'n Reformatoriese denkraamwerk het Christenwetenskaplikes met reg ook bedenkinge teen die byna grenslose optimisme van NLP-voorstanders aangaande alles wat terapeuties met die sogenaamde modelleringsmetode bereik sou kon word (vgl. afdeling 7.1). Sonder om te ontken dat ' $n$ mate van sukses inderdaad moontlik sou wees as ideale rolmodelle op die gedrag van mense inwerk, word 'n duidelike deterministiese tendens ontdek by NLPeksponente se siening van modellering. Om aan te voer dat kommunikatiewe modelleringsprosedures en -programme (programmering) feitlik enige vaardigheid aan ander persone sal kan oordra (vgl. Dilts, 1998:29), is antropologies, psigologies en andersins vergesog. Hierdie siening impliseer 'n deterministiese en meganiese manier om die uitnemende eienskappe van voorbeeldmense op die kliënt "oor te plant". 
Benewens die term modellering maak die begrip programmering ook 'n integrale deel uit van NLP. Die NLP-definisie van programmering behels onder meer die integrering van die "oorgeplante" uitnemende dele van ideale rolmodelle se bekwaamhede in die neurologiese sisteem van die kliënt. Christelik-Reformatories en transendentaalkrities beoordeel, kan 'n mens in hierdie programmering ' $n$ antropologiese mistasting aandui: NLP-eksponente glo dat mense (veral in onbewuste toestande) soos rekenaars geprogrammeer kan word. Die deterministiese effek van die natuurpool (wetenskapsideaal) van die humanisme is in hierdie veronderstelling duidelik sigbaar. Die feit dat die programmeringstegnieke die kliënt dikwels betrek in 'n esoteriese toestand van die onderbewyssyn, bring afstand tussen Christenwetenskaplikes (soos psigo-opvoedkundiges) en NLP-praktisyns.

'n Mens sou transendentaal- en immanent-krities nog na talle probleme aangaande NLP kon verwys, maar daar word met bogenoemde volstaan as voorbeelde van kommentaar op die denke van voorstanders van NLP vanuit 'n Christelik-Reformatoriese denkraamwerk.

\section{Samevatting}

Vanuit 'n Christelike psigo-opvoedkundige perspektief en binne die raamwerk van die Reformatoriese wysbegeerte moet die toepassing van die NLP-model op kinders, hetsy deur sielkundiges of onderwysers, afgewys word. As rede hiervoer kan aangevoer word dat enige terapeutiese en opvoedingshandelinge wat onder die primaat van die humanistiese en ander grondmotiewe en vooronderstellings bedryf word, noodwendig tot apostatiese teenstrydighede en misvorming oor die hele lewenslinie heen sal lei.

Alhoewel dit nie binne die bestek van hierdie artikel val om 'n volledige kritiese evaluering van NLP te gee nie, is dit tog noodsaaklik om te meld dat daar nie eenstemmigheid onder navorsers bestaan oor die geldigheid van NLP-konsepte en -vooronderstellings nie (vgl. byvoorbeeld Fromme \& Daniell, 1984:390; Petroski, 1985:1697; Sharpley, 1987:103). Daar moet dus in gedagte gehou word dat sommige (veral Christen-) navorsers die geldigheid van belangrike NLP-konsepte en -vooronderstellings ernstig bevraagteken, byvoorbeeld die reeds beklemtoonde onrealistiese optimisme dat alle vorme van uitnemendheid en hoë standaarde op gelyke vlak vir alle mense moontlik is. Hierdie onrealistiese optimisme oor die mens en menslike vermoëns is strydig met die godgegewe diversiteit van individuele persoon- 
likhede in die skepping. NLP, wat wel in gewildheid toeneem, het dus nie veel te bied waaroor psigo-opvoedkundiges wat vanuit 'n Reformatoriese denkraamwerk funksioneer, opgewonde behoort te raak nie. NLP steun ook te swaar op veralgemenings, gemeenplase en die algemene stand van sake.

Talle van die terapeutiese situasies wat buitendien deur nie-NLPgeoriënteerde terapeute aangewend word, kan goedskiks gebruik word om 'n Reformatoriese psigo-opvoedkundige en terapeutiese opvoedingspraktyk in werking te stel. Hierdie mikpunt kan met goeie gevolg behaal word binne die sfeer van 'n Christelik gefundeerde kosmologie en antropologie waarby die sin-verskeidenheid, -samehang en -totaliteit geld.

\section{Geraadpleegde bronne}

ALDER, H. 1996. NLP for managers: How to achieve excellence at work. Reprinted. London: Judy Piatkus.

ALDER, H. 1997. Neuro-linguistic Programming: The new art and science of getting what you want. Reprinted. London: Judy Piatkus.

ANDREAS, S. \& ANDREAS, C. 1992. Neuro-linguistic Programming. (In Budman, S.H., Hoyt, M.F. \& Friedman, S., eds. The first session in brief therapy. London: The Guilford Press. p. 14.35.)

ANDREAS, S. \& FAULKNER, C., eds. 1998. NLP: The new technology of achievement. Reprinted. London: Nicholas Brealey.

BANDLER, R. \& GRINDER, J. 1975a. The structure of magic: A book about language and therapy. Volume 1. Palo Alto: Science and Behaviour Books.

BANDLER, R. \& GRINDER, J. 1975b. Patterns of the hypnotic techniques of Milton H. Erickson. Volume 1. Cupertino: Meta Publications.

BESTER, P.C., NAINAAR, K. \& ROODT, G. 2000. Die meting van Neurolinguistiese Programmering se verteenwoordigende stelsels: 'n Eksploratiewe studie. Tydskrif vir Bedryfsielkunde, 26(1):46-54.

BLACKERBY, D.A. 1996. Rediscover the joy of learning. Oklahoma City: Success Skills.

BODENHAMER, B.G. \& HALL, L.M. 1999. The user's manual for the brain: The complete manual for Neuro-linguistic Programming practitioner certificate. Revised edition. Wales: Crown House.

CLEVELAND, B.F. 1987. Master teaching techniques: Neuro-linguistic Programming. Fourth edition. Lawrenceville: The Connecting Link.

DERKS, L. \& HOLLANDER, J. 2000. Essenties van NLP: Sleutels tot persoonlijke verandering. Vijfde druk. Utrecht: Servire.

DILTS, R.B. 1998. Modeling with NLP. Capitola: Meta Publications.

DILTS, R.B. \& GREEN, J.D. 1982. Applications of Neuro-linguistic Programming in family therapy. (In Horne, A.M. \& Ohlse, M.M. Family counseling and therapy. Itasca: Peacock Publishers. p. 214-244.)

DILTS, R.B., GRINDER, J., BANDLER, R. \& DELOZIER, J. 1980. Neurolinguistic programming. Volume 1: The study of the structure of subjective experience. Cupertino: Meta Publications. 
FROMME, D.K. \& DANIELL, J. 1984. Neurolinguistic Programming examined: Imagery, sensory mode, and communication. Journal of Counseling Psychology, 31(3):387-390.

GRINDER, J. \& BANDLER, R. 1976. The structure of magic. Volume 2. Palo Alto: Science and Behaviour Books.

GRINDER, J., DELOZIER, J. \& BANDLER, R. 1977. Patterns of the hypnotic techniques of Milton H. Erickson. Volume 2. Cupertino: Meta Publications.

HALL, L.M. 1996. The spirit of NLP: The process, meaning and criteria for mastering NLP. Wales: Crown House.

HALL, L.M. \& BODENHAMER, B.G. 1999. Glossary of terms. http://www. neurosemantics.com/Articles/Glossary.htm [24 April 2000].

JOHNSTON, C. 1998. See me, feel me, teach me. The Times Educational Supplement, 4298:6-7, Nov.

KNIGHT, S. 1996. NLP at work: The difference that makes a difference in business. Reprinted. London: Nicholas Brealey.

KORZYBSKI, A. 1958. Science and sanity: An introduction to non-Aristotelian systems and general semantics. Fourth edition. Lakeville: The International Non-Aristotelian Library.

KRUGER, J.A. 1999. NLP practitioner certificate programme. Unpublished guide for workshops. Pretoria: Success Sciences.

MACKENZIE, M.M. 1984. The metaskills model of sports counseling: Helping athletes achieve excellence. Quest, 36(2):122-133.

MATZKEN, R.H. 1998. Eine christliche Bewertung von NLP (Neurolinguistisches Programmeren). Fundamentum, 4(4):64.

O'CONNER, J. \& McDERMOTT, I. 1996. Principles of NLP. London: Thorsons.

O'CONNER, J. \& SEYMOUR, J. 1990. Introducing Neuro-linguistic Programming: The new psychology of personal excellence. London: Harper Collins.

PETROSKI, A. 1985. Representational systems in the Neurolinguistic Programming model. Dissertation Abstracts International, 46(05-B):16971698.

ROBBINS, A. 1997. Unlimited power: The new science of personal achievement. New York: Simon \& Schuster.

SCHOEMAN, P.G. 1988. Wysgerige Pedagogiek. Tweede druk. Pretoria: Sacum.

SHARPLEY, C.F. 1987. Research findings on Neurolinguistic Programming: Nonsupportive data or an untestable theory? Journal of Counseling Psychology, 34(1):103-107.

STEYN, J. 1994. Die "New Age-beweging" in die onderwys. Postdoktorale Navorsingsverslag. Vanderbijlpark: $\mathrm{PU}$ vir $\mathrm{CHO}$.

STEYN, J. 1999. A critical analysis of Neuro-linguistic Programming in the classroom. Tydskrif vir Christelike Wetenskap, 35(1-2):113-124.

STRAUSS, D.F.M. 1988. Die grondbegrippe van die sosiologie as wetenskap. Pretoria: RGN.

WALDHEIM, G.P. 1987. Understanding how students understand: A prerequisite to planning effective teaching-learning methods. Engineering Education: 306-308, Feb.

WILLIAMS, M.F. \& JACOBSON, W.H. 1989. Neurolinguistic Programming in orientation and mobility. Journal of Visual Impairment and Blindness, 83:454-456, Nov. 
WOERNER, J.J. \& STONEHOUSE, H.B. 1988. The use of the Neurolinguistic Programming model for learning success. School Science and Mathematics, 88(6):516-524, Oct.

ZASTROW, C. 1992. The practice of social work. Fourth edition. Belmont: Wadsworth.

ZASTROW, C., DOTSON, V. \& KOCH, M. 1987. The Neuro-linguistic Programming treatment approach. Journal of Independent Social Work, 1(1):29-38.

\section{Kernbegrippe:}

NLP (Neurolinguistiese Programmering)

NLP-konsepte

NLP-vooronderstellings

NLP-voorstellingsisteme

\section{Key concepts:}

NLP (Neuro-linguistic Programming)

NLP concepts

NLP presuppositions

NLP representation systems 
